\title{
AN ENVIRONMENTAL DATABASE FOR THE STATUS OF FRESHWATER IN GREECE
}

\section{A. TSOUNI \\ N. ZERVOS \\ K. HADJIBIROS* \\ A. ANDREADAKIS}

Received: $13 / 06 / 02$

Accepted: 29/10/02
National Technical University of Athens

Faculty of Civil Engineering

Department of Water Resources

Hydraulic and Maritime Engineering

9, Heroon Polytechniou GR - 157 80, Athens

* to whom all correspondence should be addressed

\section{ABSTRACT}

An environmental database has been created, recording water bodies at a national level and assembling relevant data collected by various public services and institutions in charge of water resources management and research in Greece. Data consists of physico-chemical parameters, geomorphological descriptions, inventories of fauna and flora species, environmental pressures, vulnerability evaluation and other information useful for the assessment of current and future ecological status. Data gathering has proven to be a challenging task, due to the large number and the generally small size of the surface freshwater bodies as well as the numerous competent services and institutions and the multiple and sometimes conflicting responsibilities that therefore result. The latter is also partly the cause of lack of continuity of data, gaps or sometimes questionable reliability. Performing a global data overview, we note that (a) ecological status can be characterized as good for the majority of the sites, especially for small mountain streams, and (b) the general trend in most cases is degradation of current conditions, related either to anthropogenic pressures or to human activity combined with natural factors. This database, in a more completed and enriched form, could assist in the implementation of 2000/60/EC Directive in Greece and the establishment of reference conditions of surface freshwater systems.

\section{INTRODUCTION}

Greece is a relatively small European country, with an area of $132,000 \mathrm{~km}^{2}$ and a population of about 10,000,000 inhabitants. From a geographical point of view, the country can be divided in the mainland and the surrounding islands or island groups. Sea surrounds the greatest part of the country, the coastal length reaches $16,000 \mathrm{~km}$ and there are about 140 inhabited islands. An important part of its area is mountainous, $60 \%$ is cov- ered by forests and shrub and $35 \%$ by agricultural land (Hadjibiros et al., 1997).

Greece is characterized by an adequate freshwater supply per inhabitant $\left(5.9 \times 10^{3} \mathrm{~m}^{3} \mathrm{y}^{-1} \mathrm{inh}^{-1}\right)$, as compared with other Mediterranean countries (Koussouris et al., 1990; Hadjibiros et al., 1997). During the last three decades its surface freshwater resources had to meet growing demands and environmental pressures. Surface water manage- 
ment responsibilities are divided among a large number of public institutions. This situation results in the constant reduction of availability and quality of surface water and its ecological degradation.

During the 80's and the 90's economic development and national legislation have been considerably influenced by the European Union. EU funding resources determine the economic development of the country to a very high extent. Environmental legislation and protection policies reveal a strong EU influence, although they are not always implemented in a very effective way.

Therefore, it is well understandable today that the need for sustainable water management becomes more and more pressing in Greece. So, what is required first of all is the knowledge of the present situation regarding the quality and quantity of freshwater as well as the estimation of the existing pressures on it. The scope of this paper is to contribute towards this direction, by presenting an environmental database, containing the abovementioned information. This database was created by the authors for the specific needs of Greece, in order to provide a first basic tool for water management, as required by the 2000/60/EC Directive.

\section{GENERAL CHARACTERISTICS OF GREEK WATER RESOURCES}

Greece is located in the Mediterranean climatic zone, with an uneven spatial mean annual and seasonal rainfall distribution. This fact, along with its geomorphologically young origin and variable profile, gave rise to rather small catchment areas, small lakes and relatively small rivers. A large number of relatively small water bodies have been formed, distributed throughout the country rather than few important water bodies with limited spatial distribution. It is useful to point out that (a) there are no water bodies of significant size in any of the islands, and (b) one quarter of the surface water resources of Greece originates from neighbouring countries. In fact certain large Greek rivers run only a limited part of their length located in Greece.

A crucial characteristic of the water resources in Greece is their uneven spatial distribution and their temporal flows. Generally speaking, precipitation is much more intense in the western than the eastern part of Greece, reaching (average
1981-90) $950 \mathrm{~mm}$ in the north-western part of the country (Corfu), 400 in the eastern mainland (Athens), $350 \mathrm{~mm}$ in the central Aegean islands and $700 \mathrm{~mm}$ in the eastern Aegean islands (Samos) (Hadjibiros et al., 1997). Regarding seasonal distribution, $80-90 \%$ of the annual precipitation takes place during the winter period, while the summer precipitation is variable along the north-south axis. Only one of the ten largest Greek rivers and two of the twelve largest Greek lakes are located in southern Greece, mostly in its southwestern part (Ministry of Development, 1996).

An uneven distribution pattern is also observed in country's water demand. The ThessalonikiAthens-Patra axis, which assembles most of the population and economic activities, is geographically distant from important water resources. On the other hand, peak demands for the agriculture, which happens to be the greatest water consumer, occur during the summer period. During the same period drinking water consumption is significantly increased due to tourist activity.

\section{MAIN LEGISLATION}

- Law 1650/86 "On the protection of the environment"

Aim: Protection of surface and ground water etc. Designation of the desired and permitted quality of natural water bodies.

Description: Requires monitoring of water quality at a nation-wide level.

- Law 1739/87 "On management of water resources"

Aim: The formulation of water policy based on management of the system "water resources and water uses". Satisfaction of demands and maintenance of good fresh water quality.

Description: Sets up a legislative and organizational framework for the correct management of water resources at a central and regionwide level, by dividing the country in 14 water districts. Sets guidelines for the preparation of programmes for development and utilization of water resources. Establishes monitoring control and environmental protection measures. Promotes policies intending to decrease demand and increase efficiency of water uses.

- Directive 75/440/EEC “Concerning the quality required of surface water intended for the abstraction of drinking water" 
Aim: Reduction of water pollution and protection against subsequent deterioration, protection of public health and definition of quality standards for surface water intended for the abstraction of drinking water.

Description: Surface water is divided in three categories (A1, A2 and A3), each corresponding to the appropriate standard methods of treatment. Surface water quality requirements are set out in order to consider the implementation of the respective methods of treatment sufficiently. For every parameter defining the physical, chemical and microbiological quality, both an imperative (I) and a guide (G) - desirable - limiting value are fixed.

- Directive 80/778/EEC "Relating to the quality of water intended for human consumption" Aim: Setting up of surface water quality standards for water intended for human consumption.

Description: This directive doesn't differ much from Directive 75/440/EEC relatively to the imperative (I) and guide (G) - desirable - limiting values. However, it does set stricter values for maximum allowed $\mathrm{NH}_{4}$ concentration and allows for a higher concentration of phosphorus.

- Directive 91/271/EEC "Concerning urban wastewater treatment"

Aim: The protection of the aquatic environment, especially sensitive areas, from the negative impact of inadequately treated urban wastewater, sewage sludge and industrial waste. Description: Establishes guidelines and time limits, in accordance to the population levels of settlements concerned and other criteria, for the construction of sewage pipes in all settlements, the determination of the treatment level of urban wastewater before discharge taking also into account the area's sensitivity and the reuse of sewage sludge. Guidelines concerning industrial waste discharge are also given. Requires the monitoring of treatment plants, sewage sludge disposal, all discharges and aquatic receptors (Study group, 1993).

- Directive 91/676/EEC "Concerning the protection of waters against pollution caused by nitrates from agricultural sources"

Aim: Reduction of existing pollution and prevention of future pollution of ground and surface freshwater caused directly or indirectly by nitrates originating from agricultural activities.

Description: Requires the specification of water affected by nitrate pollution, the implementation of a monitoring programme of nitric ions in surface and groundwater, the institution of a code of environmental agricultural practice and the application of action plans for sensitive areas.

- Directive 2000/60/EC "Establishing a framework for Community action in the field of water policy"

Aim: Establishment of a framework for the protection of inland surface waters, transitional waters, coastal waters and groundwater in order to (a) prevent deterioration and protect and enhance the status of aquatic ecosystems, (b) promote sustainable water use, (c) protect and improve the aquatic environment, (d) reduce and prevent pollution of groundwater, and (e) contribute to mitigating the effects of floods and droughts.

Description: Sets up an organizational framework for the management of water resources, by assigning water resources to river basin districts and requiring the identification of competent authorities responsible for their administration. Provides guidelines for programmes for the monitoring of water status. Defines strategies against water pollution, environmental quality objectives and appropriate economic measures. Requires the production, application and evaluation of a river basin management plan for each water district.

\section{WATER RESOURCES MONITORING AND MANAGEMENT REGIME}

A large number of public agencies, services and institutions are involved in water resources management, monitoring and protection. Operating on a local, regional or national level, they are usually linked to particular sectors of economic activity or higher-level public administration, aiming solely at fulfilling their own particular objectives and demands, with inefficient coordination regarding water policies. This resulted in a variety of administrative problems, including complexity, overlapping of responsibilities, conflicting situations and antagonism, as well as lack of coordinated efforts and investments, inefficient use of existing information, problems in priorities-set- 
ting and in general ineffective management of the available water resources. The recent division of the country in 14 water districts is considered to be a step in the right direction, that is towards a better cooperation of the various sectors and the establishment of a more efficient and sustainable management.

Some of the most important public organizations involved in water resources management are:

- The Ministry of Foreign Affairs (international water resources);

- The Ministry of Public Administration (general, water supply, wastewater discharge);

- The Ministry of Development (Central Water District Service, industry, water-power generation, tourism - thermal springs, research and technology, bottled water);

- The Ministry of Agriculture (irrigation, drainage, stock-breading, fishing);

- The Ministry of Environment, Regional Planning and Public Works (design and construction of water supply, wastewater discharge and irrigation infrastructures, water and environmental quality monitoring and control);

- The Ministry of Health (drinking water quality control);

- National Meteorological Service;

- Public Power Corporation (water-power generation);

- Institute of Geology and Mineral Exploration (hydrogeological research);

- Water Supply and Sewage Corporations of Athens and Thessaloniki;

- Municipal Water Supply and Sewage Corporations (in 75 cities);

- National Centre for Maritime Research (water resources research);

- Universities and other research institutions.

There are several agencies involved in the monitoring of the quality of surface waters. These include: (a) Two ministries which have established "National Water Quality Networks" for a continuous water quality monitoring system; (b) Public agencies that have developed "Water Quality Networks" for a continuous monitoring system covering needs of their own, such as the Public Power Corporation, the Water Supply and Sewage Corporation of Athens and the Municipal Water Supply and Sewage
Corporations; and (c) Research centres and universities that monitor water parameters for limited periods in specific areas in the context of research projects or environmental studies.

Regarding the two "National Water Quality Networks":

- The Ministry of Agriculture has developed a network that consists of 935 sampling points in various rivers and lakes, covering the 14 water districts of the country. The parameters measured are water discharge, physicochemical characteristics and sediment transport. This effort is mainly connected to irrigation needs; the sampling frequency is monthly.

- The Water Department of the Ministry of the Environment has designed a National Inland Water Quality Network in 1986. The lack of infrastructure and financial difficulties has delayed its implementation. Time and considerable funding from the EU proved to be necessary in order to set up and equip the appropriate water quality control laboratories. The network is operational since 1995 in 7 out of the 14 water districts, while for the water district of Thessaly measurements exist since 1988. In the other six water districts, about 1,000 samplings took place on 56 sites during 1995 and 1996. Simultaneously, in the water district of Thessaly 700 samplings took place on 45 sites. The vast majority of sampling points refer to rivers.

(Ministry of Development, 1996; Argyropoulos, 1997)

\section{A DATABASE FOR WATER BODIES}

An environmental database has been created by the authors of this paper in 2001, recording water bodies on a national level and assembling relevant data collected by various public services and institutions in charge of water resources management and research. Water sites were classified into categories according to European Union Directive 2000/60/EC. In total 674 water sites have been registered: 379 in rivers, 88 in lakes, 121 in transitional water bodies (mostly river estuaries, deltas and lagoons) and 105 in artificial or heavily modified water bodies (mostly artificial reservoirs).

Data gathering has proven to be a challenging task, due to the large number and the generally small size of the surface freshwater sites as well as 
Table 1. Data sources for the environmental database

\begin{tabular}{|l|c|c|c|c|}
\hline \multicolumn{1}{|c|}{ Data source } & $\begin{array}{c}\text { Water sites in } \\
\text { rivers }\end{array}$ & $\begin{array}{c}\text { Water sites in } \\
\text { lakes }\end{array}$ & $\begin{array}{c}\text { Transitional } \\
\text { water sites }\end{array}$ & $\begin{array}{c}\text { Artificial/Modified } \\
\text { water sites }\end{array}$ \\
\hline FILOTIS & 245 & 78 & 96 & 50 \\
\hline Ministry of Development, 1996 & 153 & 31 & 5 & 50 \\
\hline Ministry of Agriculture, 2001 & 32 & 16 & 19 & 5 \\
\hline Hadjibiros et al., 1997 & 46 & 20 & 17 & 6 \\
\hline Karydis \& Tsirtsis, 2000 & 24 & 11 & 1 & 1 \\
\hline Andreadakis \& Katsara, 1993 & 17 & 17 & 3 & 4 \\
\hline Ministry of Environment, 2000 & 1 & 2 & 0 & 0 \\
\hline Total number of water sites* & $\mathbf{3 7 9}$ & $\mathbf{8 8}$ & $\mathbf{1 2 1}$ & $\mathbf{1 0 5}$ \\
\hline
\end{tabular}

*Without overlapping

the numerous public organizations involved in raw data collection. Data was not collected directly from the public services that had performed the original measurements; databases and studies regrouping large amounts of the raw data were used instead (see Table 1) (Andreadakis \& Katsara, 1995; Goulandris Natural History Museum, 1994; Hadjibiros, 1995; Hadjibiros, 1996; Koussouris et al., 1990; Stamou et al., 1995; Ministry of Environment et al., 2000). Our primary source of data was FILOTIS, a data bank for the Greek natural environment created by the Department of Water Resources, Hydraulic and Maritime Engineering of the National Technical University of Athens.

Performing an overview of the gathered data regarding spatial representation and temporal continuity, we note that the network has a satisfactory mean sampling site density on a national scale and there have been considerable efforts for its continuous operation. However there are important problems related to many sites, so that the finally available information in certain areas can be considered insufficient.

The monitoring network is not very dense in the eastern part of the country; there are certain areas were the sampling sites are very unevenly distributed due to the lack of coordination of the services involved. This results to the creation of spatial "voids". In general, it can be stated that the spatial information available is positively linked to the importance of the water resources of an area; e.g. it is more complete if these resources have been or will be exploited for power generation.

Temporal continuity presents a much more com- plicated image. Some fundamental parameters have been surveyed for long periods of time in a majority of water bodies - especially the large ones. The Municipal Water Supply and Sewage Corporations usually have uninterrupted records for their respective drinking water supply resources. The quality of measurements is positively linked to the size of the population that is supplied by the source. However, for other water uses and particularly when additional water quality parameters are concerned, longterm gaps are encountered in many cases. This is due either to a lack of funding (e.g. for expensive biological analyses), to network malfunctioning on either a central (managers) or a branch (observers and sampling personnel) level or to a decision made by the organization in charge, as quite frequently sampling is conducted for a limited period of time and a limited number of parameters for the sole purposes of a study or a research project.

Data reliability is also questionable, especially when it is impossible to trace the original sampling, handling and analytical methods and protocols or to conduct reliability tests, based on timeseries collected from nearby sites. Inadequate equipment maintenance and calibration is also a common cause for obtaining unreliable data.

\section{ANALYTICAL DATA OVERVIEW}

All the data gathered in the context of this research was organised in distinct categories in a systematic way. This filing facilitates both the recording of new data and the quick search of the existing information. 
Table 2. Overview of assembled data

\begin{tabular}{|l|c|c|c|c|}
\hline \multicolumn{1}{|c|}{ Parameters } & $\begin{array}{c}\text { Water sites } \\
\text { in rivers }\end{array}$ & $\begin{array}{c}\text { Water sites } \\
\text { in lakes }\end{array}$ & $\begin{array}{c}\text { Transitional } \\
\text { water sites }\end{array}$ & $\begin{array}{c}\text { Artificial/Modified } \\
\text { water sites }\end{array}$ \\
\hline Physicochemical parameters & 35 & 19 & 5 & 4 \\
\hline $\begin{array}{l}\text { Geomorphological data - } \\
\text { Detailed site descriptions }\end{array}$ & 370 & 88 & 98 & 98 \\
\hline Flora and fauna & 124 & 44 & 58 & 22 \\
\hline $\begin{array}{l}\text { Environmental pressures } \\
\text { (threats \& disturbances) }\end{array}$ & 214 & 74 & 88 & 49 \\
\hline Total number of water bodies & $\mathbf{3 7 9}$ & $\mathbf{8 8}$ & $\mathbf{1 2 1}$ & $\mathbf{1 0 5}$ \\
\hline
\end{tabular}

Table 3. General information

\begin{tabular}{|c|c|c|c|c|}
\hline & $\begin{array}{c}\text { Water sites } \\
\text { in rivers }\end{array}$ & $\begin{array}{c}\text { Water sites } \\
\text { in lakes }\end{array}$ & $\begin{array}{c}\text { Transitional } \\
\text { water sites }\end{array}$ & $\begin{array}{c}\text { Artificial/Modified } \\
\text { water sites }\end{array}$ \\
\hline Region & + & + & + & + \\
\hline Municipality & + & + & + & + \\
\hline Height $(\mathrm{m})$ & + & + & + & + \\
\hline Length (km) & + & & & + \\
\hline Width (m) & + & & & \\
\hline $\begin{array}{l}\text { Depth }(\mathrm{m}) \\
\text { - mean } \\
\text { - maximum }\end{array}$ & + & $\begin{array}{l}+ \\
+\end{array}$ & $\begin{array}{l}+ \\
+\end{array}$ & \\
\hline Water level $(\mathrm{m})^{1}$ & & + & & \\
\hline Surface $\left(\mathrm{km}^{2}\right)^{1}$ & & + & + & + \\
\hline Volume $\left(\mathrm{hm}^{3}\right)^{1}$ & & + & & \\
\hline Storage capacity $\left(\mathrm{hm}^{3}\right)$ & & + & & \\
\hline Dam/diversion & + & & & + \\
\hline Dam height $(\mathrm{m})$ & & & & + \\
\hline Dam width $(\mathrm{m})$ & & & & + \\
\hline Maximum storage capacity $\left(\mathrm{hm}^{3}\right)$ & & & & + \\
\hline Useful storage capacity $\left(\mathrm{hm}^{3}\right)$ & & & & + \\
\hline Installed power capacity (MW) & & & & + \\
\hline Net annual power generation (GWh) & & & & + \\
\hline Sources & + & + & & \\
\hline Tributaries / alimentation & + & & + & \\
\hline River course & + & & & \\
\hline Estuary / confluence & + & + & + & \\
\hline Climate & & + & & \\
\hline Description / other information & + & + & + & + \\
\hline
\end{tabular}

1: Mean annual values

Analytically, assembled data (Table 2) consists of physico-chemical parameters, geomorphological data and detailed site descriptions, inventories of fauna and flora species and environmental pressures. Geomorphological data and detailed site descriptions (Tables 3, 4 and 5) provide information 
Table 4. Hydrological data

\begin{tabular}{|c|c|c|c|c|}
\hline & $\begin{array}{l}\text { Water sites } \\
\text { in rivers }\end{array}$ & $\begin{array}{l}\text { Water sites } \\
\text { in lakes }\end{array}$ & $\begin{array}{c}\text { Transitional } \\
\text { water sites }\end{array}$ & $\begin{array}{c}\text { Artificial/Modified } \\
\text { water sites }\end{array}$ \\
\hline $\begin{array}{l}\text { Catchment area } \\
\text { - surface }\left(\mathrm{km}^{2}\right) \\
\text { - limits } \\
\text { - sub-catchment areas } \\
\text { - runoff }\left(\mathrm{hm}^{3}\right)\end{array}$ & $\begin{array}{l}+ \\
+ \\
+ \\
+\end{array}$ & $\begin{array}{l}+ \\
+ \\
+\end{array}$ & & $\begin{array}{l}+ \\
+\end{array}$ \\
\hline $\begin{array}{l}\text { Precipitation }(\mathrm{mm}) \\
\text { - mean annual } \\
\text { - mean monthly }\end{array}$ & $\begin{array}{l}+ \\
+\end{array}$ & $\begin{array}{l}+ \\
+\end{array}$ & & + \\
\hline Mean evaporation $(\mathrm{mm})$ & & + & & \\
\hline Surface runoff potential $\left(\mathrm{hm}^{3}\right)$ & & + & & \\
\hline $\begin{array}{l}\text { Runoff }\left(\mathrm{hm}^{3}\right) \\
\text { - surface (mean annual) } \\
\text { - surface (July) } \\
\text { - natural (mean annual) } \\
\text { - surface runoff coefficient } \\
\text { - runoff penetration coefficient }\end{array}$ & $\begin{array}{l}+ \\
+ \\
+ \\
+ \\
+\end{array}$ & & & + \\
\hline $\begin{array}{l}\text { Discharge }\left(\mathrm{m}^{3} \mathrm{~s}^{-1}\right) \\
\text { - mean annual } \\
\text { - minimum } \\
\text { - maximum } \\
\text { - mean monthly } \\
\text { - mean monthly (July) } \\
\text { - KKenvironmental conservation }\end{array}$ & $\begin{array}{l}+ \\
+ \\
+ \\
+ \\
+\end{array}$ & + & + & \\
\hline Mean annual inflow $\left(\mathrm{hm}^{3}\right)$ & & & & + \\
\hline Water release $\left(\mathrm{m}^{3} \mathrm{~s}^{-1}\right)$ & & & & + \\
\hline Water release capacity $\left(\mathrm{m}^{3} \mathrm{~s}^{-1}\right)$ & & & & + \\
\hline Maximum water withdrawal $\left(\mathrm{hm}^{3}\right)$ & & & & + \\
\hline Mean annual water stock $\left(\mathrm{hm}^{3}\right)$ & & + & & \\
\hline Mean annual water balance $\left(\mathrm{hm}^{3}\right)$ & & + & & \\
\hline
\end{tabular}

about the site's physical morphology, petrographic composition, importance as natural habitat, current trophic state, water uses and future projects, as well as any other information which will help to evaluate its current ecological status.

Flora and fauna inventories (Table 5) provide information on the overall ecosystem structure and functioning. Certain species are excellent ecological and, indirectly, biodiversity indicators, especially when they occupy a high position in the trophic networks. Other useful information is related to the existence of endemic species and subspecies and the likeliness of the site to consti- tute a possible refuge and reproduction area for endangered, threatened or rare species. A detailed catalogue of flora and fauna (including ichthyofauna) species and subspecies is available for each registered site. Greek freshwater fish fauna should be considered as one of the richest in Europe (Economidis, 1992).

Physicochemical parameter (Tables 6, 7 and 8) time-series exist for the most important water resources, usually rivers, lakes and artificial reservoirs used for water supply or/and irrigation. They constitute the essential data upon which the chemical status of the water site can be evaluated. 
Table 5. Fauna, flora, environmental pressures and other ecological parameters

\begin{tabular}{|l|c|c|c|c|}
\hline & $\begin{array}{c}\text { Water sites } \\
\text { in rivers }\end{array}$ & $\begin{array}{c}\text { Water sites } \\
\text { in lakes }\end{array}$ & $\begin{array}{c}\text { Transitional } \\
\text { water sites }\end{array}$ & $\begin{array}{c}\text { Artificial/Modified } \\
\text { water sites }\end{array}$ \\
\hline Biodiversity & + & + & + & + \\
\hline Ichthyodiversity & + & + & + & + \\
\hline Threatened fish species & + & + & + & + \\
\hline Ecological importance of estuary/delta & + & + & + & + \\
\hline Water uses $^{1}$ & + & + & + & + \\
\hline Environmental pressures & + & & + \\
\hline Trophic state & + & + & + & + \\
\hline Eutrophication limiting factor & + & + & + & + \\
\hline Condition (ecological status) & + & + & + & + \\
\hline Trend & + & + & + & + \\
\hline Works under construction & + & + & + & + \\
\hline Other information & + & + & + \\
\hline
\end{tabular}

${ }^{1}$ Irrigation, water supply, hydropower generation, fishing/aquaculture, tourism, recreation, hot springs

${ }^{2}$ See text for complete list

${ }^{3}$ Hyperoligotrophic, oligotrophic, mesotrophic, eutrophic, hypereutrophic

Environmental pressures on surface freshwater ecosystems are almost entirely anthropogenic. They are related, either directly or indirectly, to the human activity in the proximity or the greater catchment area of the water body. The following pressures constitute causes for ecological degradation:

- Urban wastewater discharge;

- Industrial wastewater discharge;

- Pollution from agricultural activities (use of fertilizers);

- Use of pesticides and insecticides;

- Excessive water withdrawal for water supply, irrigation or other uses;

- Drainage for agricultural purposes;

- Eutrophication;

- Dam construction;

- River flow diversions;

- Sand and clay abstraction;

- Excessive fishing;

- Pollution from aquaculture;

- Nuisance from building activities;

- Nuisance from mining activities.

\section{ECOLOGICAL STATUS}

During the last centuries surface freshwater aquatic systems in Greece have mainly followed the slow rhythm of natural changes, with little or no influence from human activities and hence diversion from the natural state (Hadjibiros et al., 1997).

However, after the sixties, in a number of water bodies situated either in the proximity of urban areas or in regions with increased agricultural and industrial activity signs of pollution have become apparent. Gradually, the phenomena have grown both in intensity and in extent, while recently they are starting to influence smaller and previously unattained water bodies. At the same time, the growing demand for drinking water supply and irrigation resulted in an intense and frequently unreasonable exploitation of water resources. Consequently, available water quantities are presently declining and large areas have or soon will become deficient in water. Water demands in many cases are met by transporting water over long distances, thus resulting in increased both capital, operational and maintenance costs.

The ecological status is still quite good in the majority of the country's water sites (Table 9). This is in compliance with another indicator, the wealth of ichthyofauna, which demonstrates that aquatic systems in Greece, both large and small, have been - at least until recently - in very good condition. Of all the water sites that can be evaluated on the basis of available data, an overwhelming $80 \%$ of rivers, $60 \%$ of lakes, $66 \%$ of transitional and $79 \%$ of artificial or heavily modified 
Table 6. Physico-chemical parameters

\begin{tabular}{|c|c|c|c|c|}
\hline & $\begin{array}{l}\text { Water sites } \\
\text { in rivers }\end{array}$ & $\begin{array}{l}\text { Water sites } \\
\text { in lakes }\end{array}$ & $\begin{array}{c}\text { Transitional } \\
\text { water sites }\end{array}$ & \begin{tabular}{|c|}
$\begin{array}{c}\text { Artificial/Modified } \\
\text { water sites }\end{array}$ \\
\end{tabular} \\
\hline Air temperature $\left({ }^{\circ} \mathrm{C}\right)$ & + & + & & \\
\hline Water temperature $\left({ }^{\circ} \mathrm{C}\right)$ & + & + & + & \\
\hline $\mathrm{pH}$ & + & + & + & \\
\hline Secchi depth (m) & & + & + & \\
\hline $\begin{array}{l}\text { Conductivity }\left(\mu \mathrm{mhos} \mathrm{cm}^{-1}\right) \\
\text { Conductivity }\left(\mu \mathrm{S} \mathrm{cm}^{-1}\right)\end{array}$ & + & $\begin{array}{l}+ \\
+\end{array}$ & $\begin{array}{l}+ \\
+\end{array}$ & \\
\hline Total alkalinity $\left(\mathrm{mval} \mathrm{l}^{-1}\right)$ & & + & + & \\
\hline Alkalinity degree $\mathrm{Na} \mathrm{( \% )}$ & + & + & + & \\
\hline Total hardness $\left(\mathrm{mgCaCO}_{3} \mathrm{l}^{-1}\right)$ & + & + & + & \\
\hline Temporary hardness $\left(\mathrm{mgCaCO}_{3} \mathrm{l}^{-1}\right)$ & + & + & + & \\
\hline Permanent hardness $\left(\mathrm{mgCaCO}_{3} \mathrm{l}^{-1}\right)$ & + & + & + & \\
\hline Calcium hardness $\left(\mathrm{mgCaCO}_{3} \mathrm{l}^{-1}\right)$ & + & + & + & \\
\hline Magnesium hardness $\left(\mathrm{mgCaCO}_{3} \mathrm{l}^{-1}\right)$ & + & + & + & \\
\hline S.A.R. & + & + & + & \\
\hline Water category ${ }^{1}$ & + & + & + & \\
\hline $\mathrm{DO}\left(\mathrm{mg} \mathrm{l}^{-1}\right)$ & & + & + & \\
\hline Saturation level (\%) & + & + & + & \\
\hline $\mathrm{Na}\left(\right.$ meq l $\left.^{-1}\right)$ & + & + & + & \\
\hline Residual $\mathrm{Na}$ (meq $\mathrm{l}^{-1}$ ) & + & + & + & \\
\hline $\mathrm{Ca}\left(\right.$ meq l $\left.^{-1}\right)$ & + & + & + & \\
\hline $\mathrm{Mg}\left(\right.$ meq l $\left.^{-1}\right)$ & + & + & + & \\
\hline $\begin{array}{l}\mathrm{Cl}(\text { meq l} \\
\left.1^{-1}\right) \\
\mathrm{Cl}\left(\mathrm{mval} \mathrm{l}^{-1}\right)\end{array}$ & + & $\begin{array}{l}+ \\
+\end{array}$ & $\begin{array}{l}+ \\
+\end{array}$ & \\
\hline $\begin{array}{l}\mathrm{SO}_{4}\left(\mathrm{meq} \mathrm{l}^{-1}\right) \\
\mathrm{SO}_{4}\left(\mathrm{mval} \mathrm{l}^{-1}\right)\end{array}$ & + & $\begin{array}{l}+ \\
+\end{array}$ & $\begin{array}{l}+ \\
+\end{array}$ & \\
\hline $\mathrm{HCO}_{3}\left(\right.$ meq $\left.^{-1}\right)$ & + & + & + & \\
\hline $\mathrm{CO}_{3}\left(\right.$ meq l$\left.^{-1}\right)$ & + & + & + & \\
\hline Total anions and cations (meq $\left.~^{1-1}\right)$ & + & + & + & \\
\hline
\end{tabular}

Mean, minimum and maximum values.

${ }^{1} \mathrm{C} 1 \mathrm{~S} 1, \mathrm{C} 2 \mathrm{~S} 1, \mathrm{C} 3 \mathrm{~S} 1, \mathrm{C} 5 \mathrm{~S} 3, \mathrm{C} 5 \mathrm{~S} 4, \mathrm{C} 3 \mathrm{~S} 2, \mathrm{C} 4 \mathrm{~S} 4, \mathrm{C} 4 \mathrm{~S} 3$,

Table 7. Heavy metals

\begin{tabular}{|c|c|c|c|c|}
\hline & $\begin{array}{c}\text { Water sites } \\
\text { in rivers }\end{array}$ & $\begin{array}{c}\text { Water sites } \\
\text { in lakes }\end{array}$ & $\begin{array}{c}\text { Transitional } \\
\text { water sites }\end{array}$ & $\begin{array}{c}\text { Artificial/Modified } \\
\text { water sites }\end{array}$ \\
\hline $\mathrm{Cd}(\mathrm{ppb})$ & + & + & + & \\
\hline $\mathrm{Co}(\mathrm{ppb})$ & & & + & \\
\hline $\mathrm{Cr}(\mathrm{ppb})$ & & + & + & \\
\hline $\mathrm{Cu}(\mathrm{ppb})$ & & + & + & \\
\hline $\mathrm{Ni}(\mathrm{ppb})$ & & + & & \\
\hline $\mathrm{Pb}(\mathrm{ppb})$ & & + & + & \\
\hline $\mathrm{Zn}(\mathrm{ppb})$ & & + & + & \\
\hline $\mathrm{Hg}(\mathrm{ppb})$ & + & + & + & \\
\hline $\mathrm{As}(\mathrm{ppb})$ & & + & + & \\
\hline
\end{tabular}

Mean, minimum and maximum values 
Table 8. Nutrients and organic substances

\begin{tabular}{|c|c|c|c|c|}
\hline & $\begin{array}{c}\text { Water sites } \\
\text { in rivers }\end{array}$ & $\begin{array}{l}\text { Water sites } \\
\text { in lakes }\end{array}$ & $\begin{array}{c}\text { Transitional } \\
\text { water sites }\end{array}$ & $\begin{array}{c}\text { Artificial/Modified } \\
\text { water sites }\end{array}$ \\
\hline $\mathrm{N}\left(\mu \mathrm{g} \mathrm{1^{-1 }}\right)$ & & + & + & \\
\hline $\mathrm{NO}_{2}\left(\mathrm{mg} \mathrm{l}^{-1}\right)$ & & $++^{1}$ & & \\
\hline $\mathrm{NO}_{2}-\mathrm{N}\left(\mu \mathrm{gl}^{-1}\right)$ & & + & + & \\
\hline $\mathrm{NO}_{2}-\mathrm{N}(\mathrm{ppm})$ & + & & & \\
\hline $\mathrm{NO}_{3}\left(\mathrm{mg} \mathrm{l}^{-1}\right)$ & + & & + & \\
\hline $\mathrm{NO}_{3}-\mathrm{N}\left(\mathrm{mg} \mathrm{l}^{-1}\right)$ & + & + & + & + \\
\hline $\mathrm{NO}_{3}-\mathrm{N}(\mathrm{ppm})$ & + & & & \\
\hline $\mathrm{NH}_{4}\left(\mathrm{mg} \mathrm{l}^{-1}\right)$ & & +1 & & \\
\hline $\mathrm{NH}_{4}-\mathrm{N}\left(\mathrm{mg} \mathrm{l}^{-1}\right)$ & + & + & + & + \\
\hline $\mathrm{NH}_{4}-\mathrm{N}(\mathrm{ppm})$ & + & & & \\
\hline $\mathrm{P}-\mathrm{PO}_{4}\left(\mathrm{mg} \mathrm{m}^{-3}\right)$ & + & + & & \\
\hline $\mathrm{P}^{-} \mathrm{PO}_{4}\left(\mu \mathrm{g} \mathrm{l}^{-1}\right)$ & & + & + & \\
\hline Total P $\left(\mathrm{mg} \mathrm{l}^{-1}\right)$ & + & + & + & + \\
\hline Total P $\left(\mathrm{mg} \mathrm{l}^{-1}\right)$ & & $++^{1}$ & & \\
\hline Total P $\left(\mu \mathrm{g} \mathrm{l}^{-1}\right)$ & & + & + & \\
\hline Total P (ppm) & + & & & \\
\hline Total Organic Carbon $\left(\mathrm{mg} \mathrm{l}^{-1}\right)$ & + & & + & \\
\hline Chlorophyll-a & & + & + & \\
\hline
\end{tabular}

Mean, minimum and maximum values unless mentioned otherwise

${ }^{1}$ Single measurement (Ministry of Development, 1996)

Table 9. Ecological status of water sites

\begin{tabular}{|c|c|c|c|c|c|c|c|c|}
\hline \multirow[t]{2}{*}{ Condition } & \multicolumn{2}{|c|}{$\begin{array}{l}\text { Water sites } \\
\text { in rivers }\end{array}$} & \multicolumn{2}{|c|}{$\begin{array}{c}\text { Water sites } \\
\text { in lakes }\end{array}$} & \multicolumn{2}{|c|}{$\begin{array}{c}\text { Transitional } \\
\text { water sites }\end{array}$} & \multicolumn{2}{|c|}{$\begin{array}{c}\text { Artificial/Modified } \\
\text { water sites }\end{array}$} \\
\hline & & $(\%)$ & & $(\%)$ & & $(\%)$ & & $(\%)$ \\
\hline High & 47 & 23 & 10 & 14 & 8 & 9 & 4 & 9 \\
\hline Good & 118 & 57.5 & 33 & 46 & 52 & 57 & 30 & 70 \\
\hline Moderate/poor & 39 & 19 & 26 & 37 & 30 & 33 & 9 & 21 \\
\hline $\mathrm{Bad}$ & 1 & 0.5 & 2 & 3 & 1 & 1 & - & - \\
\hline TOTAL & \multicolumn{2}{|c|}{$205 / 379$} & \multicolumn{2}{|c|}{$71 / 88$} & \multicolumn{2}{|c|}{$91 / 121$} & \multicolumn{2}{|c|}{$43 / 105$} \\
\hline
\end{tabular}

water bodies appear to be either practically undisturbed (i.e. in natural conditions) or in good environmental status. It is essential to note here that the above percentages probably underestimate the existing situation, as there is lack of information regarding the smaller, more remote and therefore least probable to be polluted water sites. The unusual high percentage of well performing artificial or heavily modified water sites can be explained by the fact that they represent a large number of artificial reservoirs, which are located in remote and sparsely inhabited areas. Natural lakes tend to be in a worse condition (40\% rated moderate/poor or bad) since they have been for long primary receptors for wastewater - frequently untreated - and agricultural runoff, while the restoration process is relatively slow (Stanners \& Bourdeau, 1995).

As satisfactory as the current situation may be, future predictions are less optimistic (Table 10). Current trends clearly indicate an ongoing deterioration process. There are no signs of improvement 
Table 10. Ecological status evolution in recorded water sites

\begin{tabular}{|l|c|c|c|c|c|c|c|c|}
\hline \multirow{2}{*}{ Trend } & \multicolumn{2}{|c|}{ Water sites in rivers } & \multicolumn{2}{c|}{ Water sites in lakes } & \multicolumn{2}{c|}{$\begin{array}{c}\text { Transitional water } \\
\text { sites }\end{array}$} & \multicolumn{2}{c|}{$\begin{array}{c}\text { Artificial / Modified } \\
\text { water sites }\end{array}$} \\
\cline { 2 - 9 } & & $(\%)$ & & $(\%)$ & & $(\%)$ & & $(\%)$ \\
\hline $\begin{array}{l}\text { Improvement } \\
\text { Restoration }\end{array}$ & 8 & 4 & - & - & - & - & 4 & 10 \\
\hline $\begin{array}{l}\text { Stability } \\
\text { Conservation }\end{array}$ & 88 & 46 & 20 & 30 & 23 & 27 & 15 & 36 \\
\hline $\begin{array}{l}\text { Slow } \\
\text { degradation }\end{array}$ & 78 & 40 & 34 & 51 & 35 & 41 & 17 & 40 \\
\hline $\begin{array}{l}\text { Fast } \\
\text { degradation }\end{array}$ & 19 & 10 & 13 & 19 & 27 & 32 & 6 & 14 \\
\hline TOTAL & \multicolumn{2}{|c|}{$\mathbf{1 9 3 / 3 7 9}$} & \multicolumn{2}{|c|}{$\mathbf{6 7} / \mathbf{8 8}$} & \multicolumn{2}{|c|}{$\mathbf{8 5} / \mathbf{1 2 1}$} & \multicolumn{2}{|c|}{$\mathbf{4 2} / \mathbf{1 0 5}$} \\
\hline
\end{tabular}

and only a third of the water sites seem to be able to preserve their current status, even in cases where the status in question is not satisfactory. Two thirds of the lakes and transitional water sites show signs of slow to rapid degradation, while rivers and artificial and heavily modified water sites are in a slightly better position (50\%). Transitional water sites seem to be the most vulnerable, since $19 \%$ is rapidly losing its ecological value.

The causes of this situation are closely linked to the recent accelerated economic activity and development of the country. Rapidly increasing water demand, extensive infrastructure construction (e.g. tourist installations), new public and private projects for water abstraction, an absence of coordination among the various institutions involved in water management, the lack of a longterm water and environment conservation strategy and the urge to immediately satisfy the needs especially in the rural areas - without taking into account the long term implications lead to the creation of numerous new pressures and the subsequent degradation of water resources at a national scale. In addition, agricultural runoff presently constitutes the major pollution factor, due to its heavy pollution loads and its non-point source nature. Therefore, addressing this specific problem is a difficult and time-consuming process.

Finally, it should also be mentioned that the large rivers in the northern part of the country are subject to upstream pollution originating from the countries they cross before entering the Greek territory.

\section{SURFACE WATER QUALITY CRITERIA}

Before adopting a suitable policy aiming to reverse the current situation, it is essential to set quality objectives to be attained; in other words, reference conditions must be specified. In order to determine reference conditions for surface waters, it is necessary to establish a number of environmental quality criteria to be fulfilled, with respect to each category of water bodies. These criteria should provide general guidelines aiming to define "good surface water status" and must combine precision with flexibility and adaptability, since the particular characteristic, i.e. environmental context and evolution perspectives of a water body, should always be taken into account in the process of defining reference conditions. These criteria can be classified in three categories:

a) Water uses oriented criteria, which aim to provide a satisfactory environment for all "users" of the water resource. The word "user" has here a broader meaning, standing for living organisms - which "use" the aquatic environment - as well as human activities. These criteria are the following:

- Populations of all native species should achieve a safe level.

- Reference conditions should guarantee the balanced functioning of the ecosystem and the ability to overcome possible short-term disturbances (accidents etc).

- All quantity, quality and environmental criteria set by legislation and water management agencies (water users) for existing or future water uses (water supply, irrigation, 
aquaculture, recreation or other) should be fulfilled.

- An additional criterion applies to the particular case of transitional waters: The intrinsic character of transitional waters must always be preserved. In other words, the balance between freshwater flows and coastal water must remain within natural limits.

b) Economic feasibility oriented criteria which can be formulated as follows: The goal of the strategic management and restoration policy will be the achievement of the highest possible grade of ecological status in each water body, provided that the cost for the implementation of measures required to achieve that status: (1) is not disproportionably high with regard to the benefits gained - alias improvement of environmental status, (2) does not compromise the economic performance of activities related to the water resource and (3) does not exhaust economic resources that could have been allocated elsewhere (other water bodies) to obtain better environmental results.

c) Naturalness oriented criteria, which do not take into account financial costs but aim at reestablishing the natural conditions of the water body, a zero-pollution level among other properties. This of course may be impossible, since certain water bodies have been subjected to anthropogenic influence for so long that one can only speculate about their pristine natural conditions. In other cases, the measures to be undertaken may be extremely expensive, so it may be in our best interest to accept a certain level of ecological degradation and allocate the economic resources in better performing environmental projects. For artificial water bodies, for which by definition we have no data concerning reference conditions, this criterion aims to achieve the best possible surface water quality status (i.e. good surface water quality potential) as this can be determined by neighbouring and/or similar water bodies.

Bearing in mind that the final aim is the longterm conservation of good surface water quality and the sustainable use of the water body, all three groups of criteria should be combined and gradually implemented, in accordance with the particular characteristics of each river basin district and of each water body.

\section{ENVIRONMENTAL POLICY AND RESEARCH NEEDS}

A national long-term environmental and water quality improvement policy comprises a number of actions and research needs intending to optimise water management on a local (water body), regional (River Water Basin District) and national level.

- Since each catchment area faces different problems and therefore requires a particular management scheme, it is essential to set up and start operating the River Water Basin Districts (RWBD), as these are defined by the law 1739/87 and the European Union Directive 2000/60/EC. These authorities should be completely responsible for water quality monitoring and management within their respective area.

- All existing competent public institutions and services responsible for water management should either be incorporated or attached to the RWBD. The latter will be responsible for the coordination, cooperation and information exchange between the depending services, for the efficient operation of hydraulic works and for the control and preservation of water quality status.

- A central authority, responsible for the coordination and cooperation of RWBD should be established. The same authority will be responsible for the overall operation of the national water quality surveillance networks and for the collection, treatment and storage of data.

- The National Database of Hydrological and Meteorological Information (www.chi.civil. ntua.gr) should be developed and used for water resources management, as it provides useful information for the protection, and rational use of the water resources in the national level.

- Water quality surveillance networks should be designed and implemented at a national scale in order to provide adequate spatial and continuous temporal information, concerning both the chemical and the ecological water quality status. Sampling, handling and analytical techniques should be standardized, in order to facilitate data comparison and guarantee its reliability.

- Water resources management studies must be conducted in order to define RWBD management plans. Water balances for each district 
(available resources and demand for various uses) will ultimately provide a series of scenarios for the development and exploitation of water resources in the corresponding region, making thus possible the realization and optimisation of a large-scale management strategy and the conservation and cautious allocation of water. The RWBD management plans should be evaluated at their end so as to assess their performance.

- In the context of RWBD management plans, measures to stabilize degrading surface water quality as a first step and restore good surface water quality status as a second must be undertaken, according to the environmental quality criteria mentioned above. Sensitive areas, as defined by international conventions and previous studies, should be given top priority. The same applies to water bodies that constitute ecological habitats refuge for protected or endangered species.

- Cooperation and negotiation with neighbouring countries for the sustainable management of shared water resources should be promoted.

- Strategic environmental impact assessment studies for policies, plans and programmes should be conducted before their implementation.

- Environmental impact assessment studies of engineering works (hydroelectric dams, irrigation and drainage systems, water abstraction etc.) must take into account the effects caused by the project in question in the greater area (river basin) in which it belongs and not just in the local area.

\section{CONCLUSION}

Adaptation to the European Union Directive 2000/60/EC and necessary actions for the assessment of freshwater ecological status in Greece have to overcome the following important setbacks:

- The existence of numerous small water bodies of rather small size;

- The freshwater data which are up-to-now unreliable due to their inadequate spatial representation and temporal continuity;

- The large number of public agencies, services and institutions which are involved in raw data collection, water resources management, monitoring and protection and are operating on a local, regional or national level, with administrative problems and inefficient coordination regarding water policies;

- The incorporation of european legislation, the adaptation of existing national legislation and the strict implementation of required measures;

- The organisation, funding and operation of surface water quality monitoring networks;

- The lack of experience in water resources management, especially at the local level.

It is critical to face and resolve these problems as soon as possible, because even though most water bodies presently maintain a good quality status, there is a clear trend towards ecological degradation. In this context, the development of a database for water bodies, such as the one presented herein, could constitute a useful and effective tool.

\section{REFERENCES}

Andreadakis, A.D. and Katsara, A. (1993), Research project "Water quality assessment of surface and ground waters", Final technical report "Determination of sensitive areas in Greece with regard to nitrate pollution of agricultural origin", National Technical University of Athens.

Andreadakis, A.D. and Katsara, A. (1995), Quality characteristics of surface and sea waters in Greece in relation to European Union legislation, Wat. Sci. Tech. 32, 183-190.

Argyropulos, D. (1997), Quality of inland surface waters in Greece, Technical report, Ministry of Environment, Regional Planning and Public Works, Athens (in Greek).

Directive 75/440/EEC of 16 June 1975 concerning the quality required of surface water intended for the abstraction of drinking water in the Member States, Official Journal of the European Communities L 194, 25/07/1975 P. 0026 - 0031.

Directive 80/778/EEC of 15 July 1980 relating to the quality of water intended for human consumption, Official Journal of the European Communities L 229, 30/08/1980 P. 0011 - 0029.

Directive 91/676/EEC of 12 December 1991 concerning the protection of waters against pollution caused by nitrates from agricultural sources, Official Journal of the European Communities L 375, 31/12/1991 P. $0001-0008$. 
Directive 91/271/EEC of 21 May 1991 concerning urban waste-water treatment, Official Journal of the European Communities L 135, 30/05/1991 P. 0040 - 0052.

Directive 2000/60/EC of the European Parliament and of the Council of 23 October 2000 establishing a framework for Community action in the field of water policy, Official Journal of the European Communities L 327, 22/12/2000 P. 0001 - 0073.

Economidis, P.S. (1992), Freshwater fish, In: Karandeinos M. (Ed.), The red data book of threatened vertebrates in Greece, Hellenic Zoological Society and Hellenic Ornithological Society, Athens (in Greek).

FILOTIS. A data bank for the Greek natural environment (2001), National Technical University of Athens (http://hydro.ntua.gr/ filotis).

Goulandris Natural History Museum (1994), Inventory of Greek wetlands as natural resources. Greek Biotope and Wetland Centre, Athens (in Greek).

Hadjibiros, K. (1995), Evaluation and classification of the important biotopes of Greece according to the criterion of threatened species of flora and fauna, In: Proceedings of the $4^{\text {th }}$ Conference on Environmental Science and Technology, University of the Aegean, Mytilini (in Greek).

Hadjibiros, K. (1996). Sustainable development in a country with extensive presence of valuable biotopes, The Environmentalist, 16, 3-8.

Hadjibiros, K., Economidis, P.S. and Koussouris, T. (1997), The ecological condition of major Greek rivers and lakes in relation to environmental pressures - Country paper of Greece. Proceedings of the Fourth EurAqua Technical Review: Let the fish speak: The quality of aquatic ecosystems as an indicator for sustainable management, pp. 103-123. European Network of Freshwater Research Organisations (EurAqua), Koblenz.

Karydis, M. and Tsirtsis, G. (2000), Eutrophication assessment in fresh waters of Greece: Development of criteria for assessing eutrophic levels in rivers and lakes, University of the Aegean, Mytilini.

Koussouris, T., Photis, G., Diapoulis, A. and Bertahas, I. (1990), Water quality evaluation in lakes of Greece. In: Wheeler D., Richarson M. and Bridges J. (Eds), Watershed 89 - The future for water quality in Europe, Advan. Wat. Poll. Contr., pp. 119-128, IAWPRC.

Law 1650/86 "On the protection of the environment”, Official Journal of the Hellenic Republic, 160A/18-10-86.

Law 1739/87 "On management of water resources”, Official Journal of the Hellenic Republic, 201A/20-11-87.

Ministry of Agriculture (2001). Water quality characteristics of rivers and lakes in Greece. Technical report, vol. I \& II, Athens.

Ministry of Development, National Technical University of Athens, Institute of Geology and Mineral Exploration \& Economic Research Centre (1996), Programme for the management of water resources in Greece, Technical report, Ministry of Development, Athens.

Ministry of Environment, Regional Planning and Public Works (2000), Programme for pollution reduction caused by List II substances (Article 7 of Council Directive 76/464/EEC) in the surface water of Lake Vegoritida, Lake Petron and River Soulou, Technical report.

Ministry of Environment, Regional Planning and Public Works, NAMA SA, ECOPOLIS SA, Jeftic, L. \& Zangrandi (2000), Study on the synthesis of MED-POL programme results for the period 1993-1997, Technical report.

National Database of Hydrological and Meteorological Information (2001). National Technical University of Athens (www.chi.civil.ntua.gr).

Stamou, A. I., Mimikou, M., Nalbandis, I. and Papanicolaou, P. (1995), Surface and groundwater monitoring and instrumentation in Greece, In: Proceedings of the Second EurAqua Technical Review Optimising freshwater data monitoring networks including links with modelling. European Network of Freshwater Research Organisations (EurAqua), Paris.

Stanners, D. and Bourdeau, P. (Eds) (1995). Europe's environment. The Dobris assessment, E.E.A., Copenhagen. Study group (1993), Actions required for the protection of the environment in Greece, Technical report (2 volumes), Technical Chamber of Greece \& European Commission, Athens. 